\title{
Spatio-temporal variation of nitrate and nitrite levels in groundwater samples from Romania
}

https://doi.org/10.21698/rjeec.2020.208

Proceedings paper

\begin{abstract}
FLORINELA PIRVU $^{1,2}$, IULIANA PAUN ${ }^{1}$, FLORENTINA LAURA CHIRIAC ${ }^{1}$, MARCELA NICULESCU ${ }^{1}$, NICOLETA VASILACHE ${ }^{1}$, LUOANA FLORENTINA PASCU ${ }^{1}$, TOMA GALAON $^{1 *}$
\end{abstract}

\author{
${ }^{I}$ National Research and Development Institute for Industrial Ecology - ECOIND, 71-73 Drumul Podu Dambovitei, \\ Sector 6, 060652, Bucharest, Romania \\ ${ }^{2}$ University Politehnica of Bucharest, 313 Splaiul Independentei, sector 6, 060042, Bucharest, Romania \\ *Corresponding author (e-mail): toma.galaon@incdecoind.ro
}

\begin{abstract}
This study investigated the spatial and temporal distribution of nitrate and nitrite concentration in groundwater from different geographical regions, in Romania. A special emphasis was put on a descriptive statistical analysis of data, namely on the determination of seasonal indices during dry and wet seasons. Nitrate and nitrite concentrations were monitored in 24 groundwater sources situated in different areas, between January 2016 and February 2020.

The obtained data showed that the values of nitrate concentrations were situated between $8.03 \mathrm{mg} / \mathrm{L}$ in the North-Eastern part of Romania, $6.37 \mathrm{mg} / \mathrm{L}$ in the South-Eastern part of the country, and $3.55 \mathrm{mg} / \mathrm{L}$ in the Western part towards the center of the country. Nitrite concentration values were situated under the national maximum admitted limit, $0.5 \mathrm{mg} / \mathrm{L}$, in all the investigated areas. The obtained data shows small changes in water quality during the monitoring period, which leads to the conclusion that, in this long interval of time, there were no significant groundwater contaminations with nitrate and nitrite. For adequate control of water pollution and rigorous management of groundwater sources, seasonal indices were calculated.
\end{abstract}

Keywords: groundwater, nitrate, nitrite, spatio-temporal variation, seasonal indices

\section{INTRODUCTION}

About $33 \%$ of the human population, globally, uses groundwater as drinking sources [1-5]. However, groundwater quality may be altered by several anthropogenic sources, such as waste disposed of by faulty practices, industrial pollution, unplanned urbanization, correlated with natural geogenic processes [6-9]. Groundwater assessment is important for identifying possible sources of contamination and assessing these contaminants to properly use this groundwater [10,11]. Intensive use of fertilizers in agriculture has changed dramatically in the last ten years, groundwater and surface water pollution has occurred through the accumulation of nutrients (nitrates, nitrites, ammonium, phosphates) from agricultural activity $[12,13]$. However, the use of large amounts of nitrogen fertilizers can contribute to anthropogenic nitrogen in groundwater around the world. Nitrogen fertilizers are quickly converted to $\mathrm{NO}_{3}{ }^{-}$which is highly water-soluble and can be easily assimilated by plants. If the amount of nitrogen added to the soil exceeds the amount adsorbed by plants, excess $\mathrm{NO}_{3}{ }^{-}$is probably slightly adsorbed by soil particles and drain from the root zone by percolating water through the soil profile and eventually accumulates in groundwater [14]. Recently, research has been conducted on nitrate pollution in groundwater from agriculture, which can cause algae flowering and eutrophication in aquifers as well as potential hazards to human health [15-17]. Exposure to high levels of nitrates has consequences for human health, by reducing the ability to carry oxygen in the blood by binding to hemoglobin or causing a condition called methemoglobinemia, which can cause asphyxiation mortality, especially in newborns. Infants under the age of six months are at high risk due to the presence of bacteria in their digestive systems that accelerate this process $[18,19]$. Information on the health effects of nitrate and nitrite showed, an association between off-spring developing adverse effects and maternal nitrate intake in drinking water. 
Experimental animal data show that reproductive toxicity could probably be associated with high levels of nitrate or nitrite exposure. Several cases of methemoglobinemia have been reported in infants in the United States using nitrate-containing water with a maximum concentration of $45 \mathrm{mg} / \mathrm{L}$ [15]. Nitrates under acidic conditions are reduced to nitrites $\left(\mathrm{NO}_{2}{ }^{-}\right)$, which in turn can combine with amino compounds (amines or amides) and can form potentially carcinogenic compounds (nitrosamines) [20]. The association between nitrate contamination of drinking water and the increased rate of cancer is supported by physiological studies. Endogenously formed Nnitroso (N-nitrosoproline) compounds can lead to different types of cancer: esophageal, gastric, nasopharyngeal [21-27].

This study presents an analytical investigation of the levels of nitrate and nitrite concentrations in 24 groundwater sources from several areas on the Romanian territory using the descriptive statistical analysis as well as seasonal indices for the dry and the wet seasons.

The analytical results were compared with the maximum admissible values imposed at the national and international level for nitrate and nitrite in groundwater (Table 1).

Table 1. Values of nitrates and nitrites in groundwater from literature data

\begin{tabular}{l|cccc}
\hline Parameters & Minimum & Maximum & $\begin{array}{c}\text { WHO limits/National } \\
\text { limits }\end{array}$ & References \\
\hline Nitrates & 1.45 & 30.8 & $50 \mathrm{mg} / \mathrm{L}$ & {$[28,30,31]$} \\
\hline Nitrites & 0.0126 & 0.128 & $0.5 \mathrm{mg} / \mathrm{L}$ & {$[29,30,32]$} \\
\hline
\end{tabular}

\section{MATERIALS AND METHODS}

\section{The climate of the study area}

The study was performed in several areas from Romania characterized by temperatecontinental climate with oceanic, ScandinavianBaltic, and sub-Mediterranean influences. Pontic influences are manifested in the SouthEastern part of Romania, with rare but torrential rains. In the eastern regions of the country, the continental character is more pronounced. In

\section{Groundwater sampling and chemical analysis}

24 groundwater sampling points situated in different parts of Romania, as indicated in Table 2, were monthly monitored for nitrates and nitrates parameters, from January 2016 to February 2020.

All selected sources were geographically located using a GPS (GARMIN Model Montana 610 navigation system,
Bucovina, the effects of the ScandinavianBaltic climate are manifested, which determines a humid and cold climate, with frozen winters. In the west part of the country, there are influences of low-pressure systems from the Atlantic zone with moderate temperatures and rich rainfall.

GPS/GLONASS navigator) (figure 1). Water samples were collected and transported in glass containers and stored at $4^{\circ} \mathrm{C}$ until appropriate analysis. Nitrate and nitrite parameters were determined using spectrophotometric methods according to the standards SR ISO 7890-3 [33] for nitrates and SR EN 26777: 02 and SR ISO 26777: 02/C91: 06 [34] for nitrites.

Table 2. The areas on the Romanian territory from which the samples were taken

\begin{tabular}{|c|c|c|}
\hline Groundwater source & Period & Sampling area \\
\hline $\begin{array}{l}\text { S1, S2, S3, S4, S5, S6, S7, } \\
\text { S9, S11, S12, S13 }\end{array}$ & 01/2016-02/2020 & The south-Eastern part of Romania \\
\hline S8, S10 & 01/2016-02/2020 & $\begin{array}{c}\text { In the West towards the central part } \\
\text { of Romania }\end{array}$ \\
\hline $\begin{array}{l}\text { S14, S15, S16, S17, S18, S19, } \\
\text { S20, S21, S22, S23, S24 }\end{array}$ & $01 / 2016-02 / 2020$ & The north-Eastern part of Romania \\
\hline
\end{tabular}




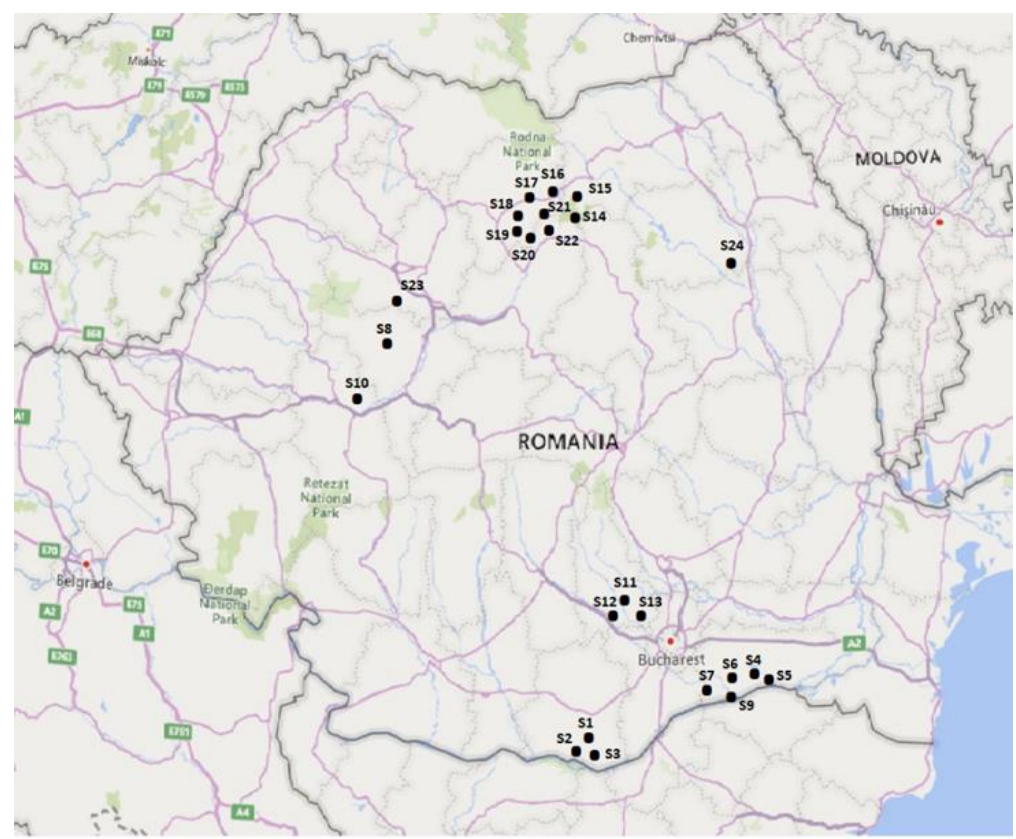

Fig. 1. Locations of sampling points

\section{RESULTS AND DISCUSSION}

Descriptive statistical analysis

In this paper, nitrites and nitrates evaluation in groundwater was achieved, examining samples taken from rural, urban, and industrial areas situated in different regions from Romania. The physical-chemical characteristics of groundwater provide essential information on the prevailing pollution conditions in the monitored area. For all samples, descriptive statistical calculations were performed over four years.

Table 3. Descriptive statistics for nitrates values in South-Eastern part of Romania

\begin{tabular}{c|ccccc}
\hline $\begin{array}{c}\text { Groundwater } \\
\text { source }\end{array}$ & Average & SD & MIN & MAX & Median \\
\hline S1 & 1.82 & 0.61 & 1.15 & 2.63 & 1.47 \\
S2 & 2.57 & 1.97 & 0.76 & 6.37 & 1.95 \\
S3 & 1.29 & 0.71 & 0.44 & 2.01 & 1.35 \\
S4 & 1.16 & 0.65 & 0.13 & 1.88 & 1.31 \\
S5 & 1.57 & 0.57 & 0.97 & 2.33 & 1.42 \\
S6 & 1.16 & 0.65 & 0.13 & 1.88 & 1.31 \\
S7 & 0.77 & 0.42 & 0.32 & 1.28 & 0.74 \\
S9 & 1.13 & 0.97 & 0.44 & 1.81 & 1.13 \\
S11 & 1.15 & 0.30 & 0.61 & 1.88 & 1.16 \\
S12 & 1.15 & 0.52 & 0.29 & 2.33 & 1.24 \\
S13 & 1.27 & 0.45 & 0.26 & 2.27 & 1.26 \\
\hline
\end{tabular}

The highest average value of $2.57 \mathrm{mg} / \mathrm{L}$, registered for nitrate, with a standard deviation value of $1.97 \mathrm{mg} / \mathrm{L}$ was detected in groundwater source S2, situated in the SouthEastern part of Romania (Table 3). For samples collected from sampling sites S14-S24, situated in the North-Eastern part of Romania, the nitrate concentration values varied from 0.05 to 4.94 $\mathrm{mg} / \mathrm{L}$, the highest value being determined in the S18 groundwater source, with a standard deviation of $1.70 \mathrm{mg} / \mathrm{L}$ (Table 4 ). 
Table 4. Descriptive statistics for nitrates values in North-Eastern part of Romania

\begin{tabular}{c|ccccc}
\hline $\begin{array}{c}\text { Groundwater } \\
\text { source }\end{array}$ & Average & SD & MIN & MAX & Median \\
\hline S14 & 0.06 & 0.02 & 0.02 & 0.09 & 0.07 \\
S15 & 0.05 & 0.02 & 0.02 & 0.09 & 0.04 \\
S16 & 1.08 & 0.16 & 0.74 & 1.33 & 1.11 \\
S17 & 1.33 & 0.58 & 0.45 & 1.88 & 1.49 \\
S18 & 4.94 & 1.70 & 2.78 & 8.03 & 4.66 \\
S19 & 0.57 & 0.87 & 0.08 & 6.01 & 0.37 \\
S20 & 1.05 & 0.42 & 0.08 & 1.35 & 1.27 \\
S21 & 2.81 & 0.77 & 0.22 & 4.55 & 3.17 \\
S22 & 1.72 & 0.58 & 0.26 & 2.64 & 1.94 \\
S23 & 2.41 & 0.26 & 1.92 & 2.75 & 2.47 \\
S24 & 3.32 & 1.25 & 1.25 & 5.14 & 3.30 \\
\hline
\end{tabular}

The data collected from the two groundwater sources located in the central area, were 0.88 $\mathrm{mg} / \mathrm{L}$ nitrate for the $\mathrm{S} 8$, with a standard deviation of $0.42 \mathrm{mg} / \mathrm{l}$ and $1.98 \mathrm{mg} / \mathrm{L}$ with a standard deviation value of $1.54 \mathrm{mg} / \mathrm{L}$ for $\mathrm{S} 10$ (Table 5).

Table 5. Descriptive statistics for nitrates values in the western and central part of Romania

\begin{tabular}{c|ccccc}
\hline $\begin{array}{c}\text { Groundwater } \\
\text { source }\end{array}$ & Average & SD & MIN & MAX & Median \\
\hline S8 & 0.88 & 0.42 & 0.57 & 1.35 & 0.71 \\
S10 & 1.98 & 1.54 & 0.48 & 3.55 & 1.92 \\
\hline
\end{tabular}

According to statistical evaluation of the $\mathrm{NO}_{3}{ }^{-}$ parameter, the maximum concentration values decrease in the South-Eastern part of the country in the sequence: $\mathrm{S} 2(6.37 \mathrm{mg} / \mathrm{L})>\mathrm{S} 1$ $(2.63 \mathrm{mg} / \mathrm{L})>\mathrm{S} 5=\mathrm{S} 12(2.33 \mathrm{mg} / \mathrm{L})>\mathrm{S} 13$ $(2.27 \mathrm{mg} / \mathrm{L})>\mathrm{S} 3(2.01 \mathrm{mg} / \mathrm{L})>\mathrm{S} 4=\mathrm{S} 6=\mathrm{S} 11$ $(1.88 \mathrm{mg} / \mathrm{L})>\mathrm{S} 9(1.81 \mathrm{mg} / \mathrm{L})>\mathrm{S} 7 \quad(1.28$ $\mathrm{mg} / \mathrm{L}$ ), while in the North-East part of the country, the maximum concentrations decrease in the following order: $\mathrm{S} 18(8.03 \mathrm{mg} / \mathrm{L})>\mathrm{S} 19$ $(6.01 \mathrm{mg} / \mathrm{L})>\mathrm{S} 24(5.14 \mathrm{mg} / \mathrm{L})>\mathrm{S} 21(4.55$

\section{Spatial variation}

The highest values determined in the studied areas were: $6.37 \mathrm{mg} / \mathrm{L}$ for the South-East part of the country, $4.94 \mathrm{mg} / \mathrm{L}$ for the North-East and $3.55 \mathrm{mg} / \mathrm{L}$ for the western area towards the central part of the country. Nitrate values in groundwater generally present a reduced variation in concentration level. Figure 2 shows the dispersion range of these concentrations as well as the statistical values for the quartile.

Figures $2 \mathrm{a}, 2 \mathrm{~b}$, and $2 \mathrm{c}$ show a rather small $\mathrm{mg} / \mathrm{L})>\mathrm{S} 23(2.75 \mathrm{mg} / \mathrm{L})>\mathrm{S} 22(2.64 \mathrm{mg} / \mathrm{L})>$ $\mathrm{S} 17(1.88 \mathrm{mg} / \mathrm{L})>\mathrm{S} 20(1.35 \mathrm{mg} / \mathrm{L})>\mathrm{S} 16(1.33$ $\mathrm{mg} / \mathrm{L})>\mathrm{S} 14=\mathrm{S} 15(0.09 \mathrm{mg} / \mathrm{L})$. For $\mathrm{S} 8$ and S10 groundwater sources, the maximum nitrate concentrations were: $1.35 \mathrm{mg} / \mathrm{L}$ and $3.55 \mathrm{mg} / \mathrm{L}$, respectively.

Regarding the nitrite parameter, all tested groundwater sources have concentrations of values situated below the maximum admitted value, which is $0.5 \mathrm{mg} / \mathrm{L}$.

dispersion of the nitrate concentration level, more precisely a median variation of the upper half, quartile on the dispersion range of the minimum and maximum values of those nitrate concentrations determined in all the evaluated areas. From Figures $2 \mathrm{a}$ and $2 \mathrm{c}$ a small variation of the dispersion range can be observed except for the groundwater source S2 as opposed to Figure $2 b$ where a higher variability of the nitrate concentration values was observed. 

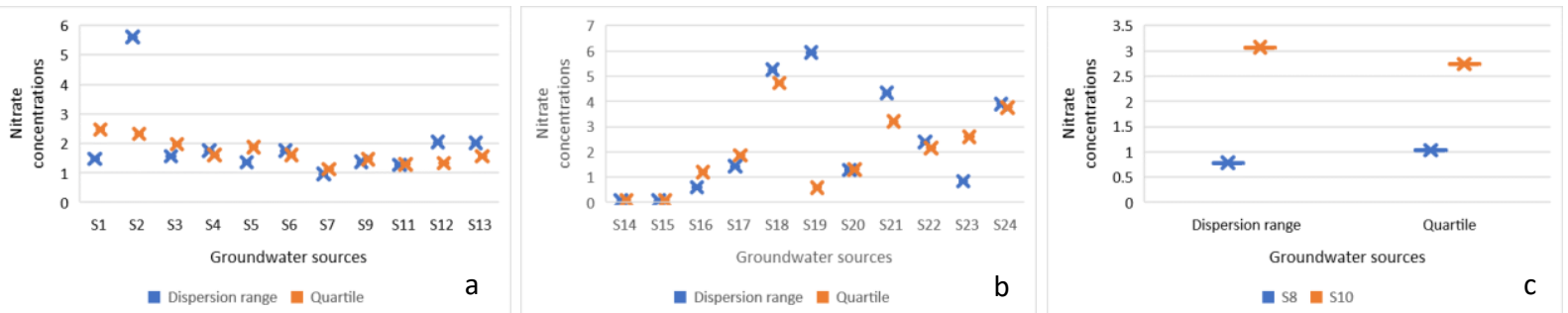

Fig. 2. Dispersion of nitrate concentrations: a) South-Eastern area of Romania, b) North-Eastern area of Romania, c) The western area towards the central part of Romania

The data of the nitrate parameter was transformed into the standard unit (Z) (Eq. 1) and its variation was presented, for all the studied areas, in Figures 3, 4, and 5.

For each sample collected during the evaluation period of this study, this parameter was calculated to observe the spatial variation for all
24 groundwater sources.

The standard unit of chemical concentrations in groundwater water [35], is defined as:

$$
Z=(X-U) / S
$$

where $\mathrm{X}$ is the raw concentration data, $\mathrm{U}$ is the mean values and $\mathrm{S}$ is the standard deviation.

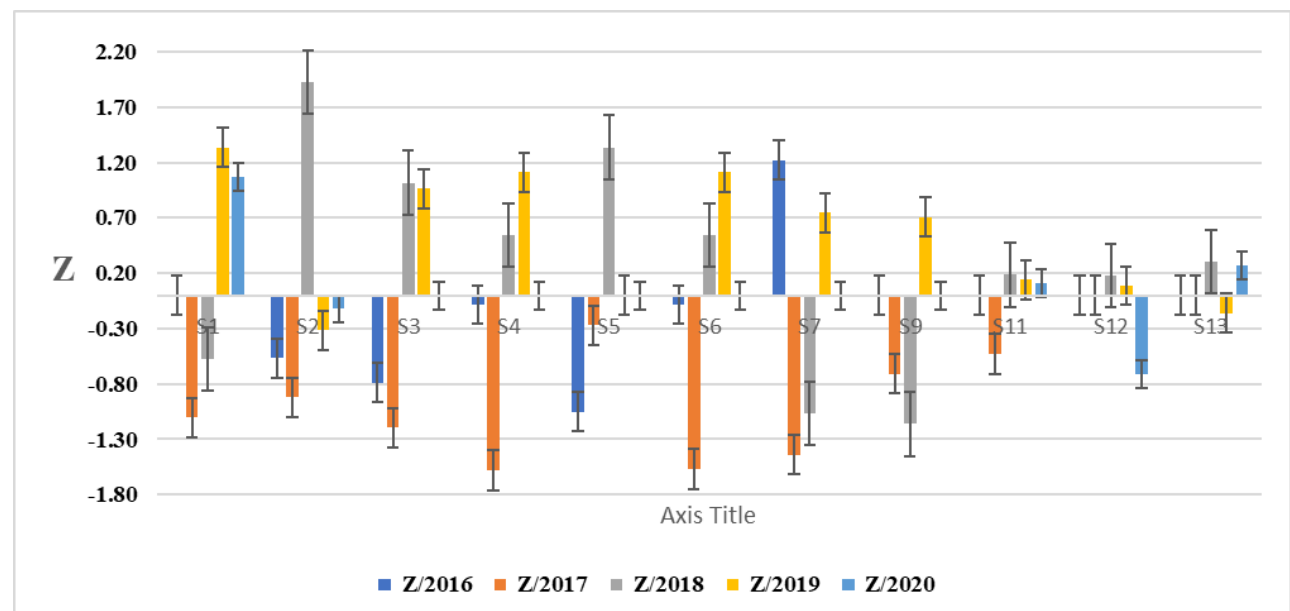

Fig. 3. Spatial variation of standard units determined in the period Jan. 2016 - Feb. 2020 for groundwater sources: S1 - S9, S11 - S13

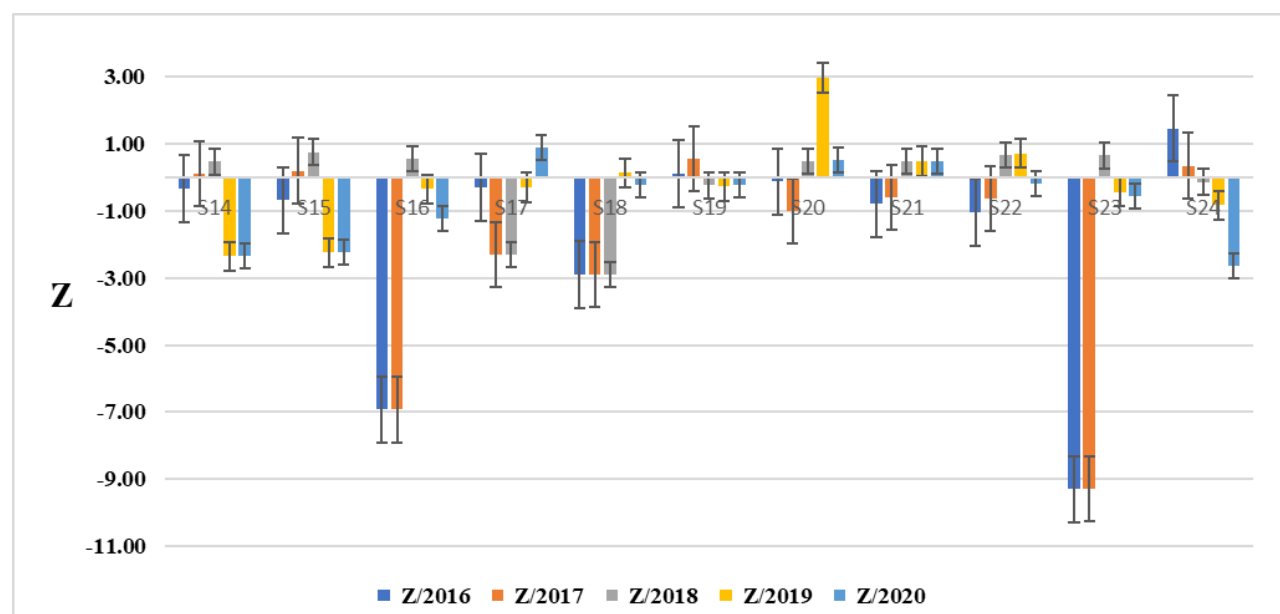

Fig. 4. Spatial variation of standard units determined in the period Jan. 2016 - Feb. 2020 for groundwater sources: S14 - S24 


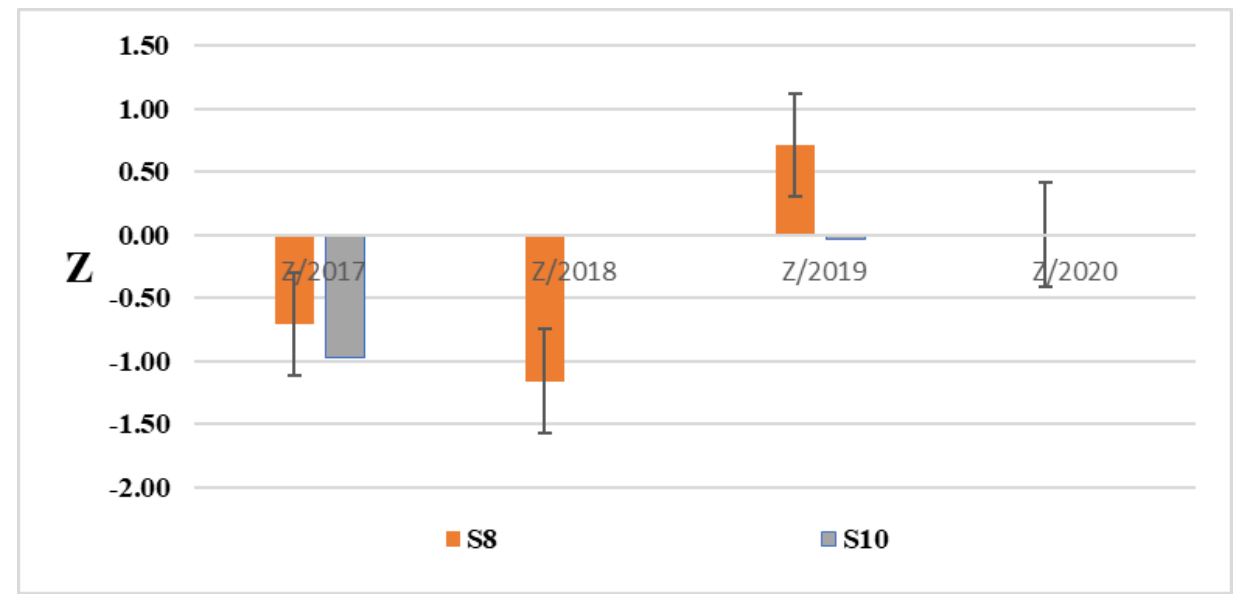

Fig. 5. Spatial variation of standard units determined in the period Jan. 2016 - Feb. 2020 for groundwater sources: S8, S10

There is a significant spatial variability for the South-Eastern area of Romania for the assessed groundwater sources. In the North-Eastern part of Romania, the largest variations of the determined standard units are at the S16 and S23 groundwater sources.

\section{Temporal distribution}

To investigate the temporal distribution of these groundwater samples over four years, seasonal indices were calculated for each source, for the dry and wet seasons. In the case of dry season,

the evaluated months were: May, June, July, August, September, October, November, and for the wet season, the evaluated months were: December, January, February, March, April.

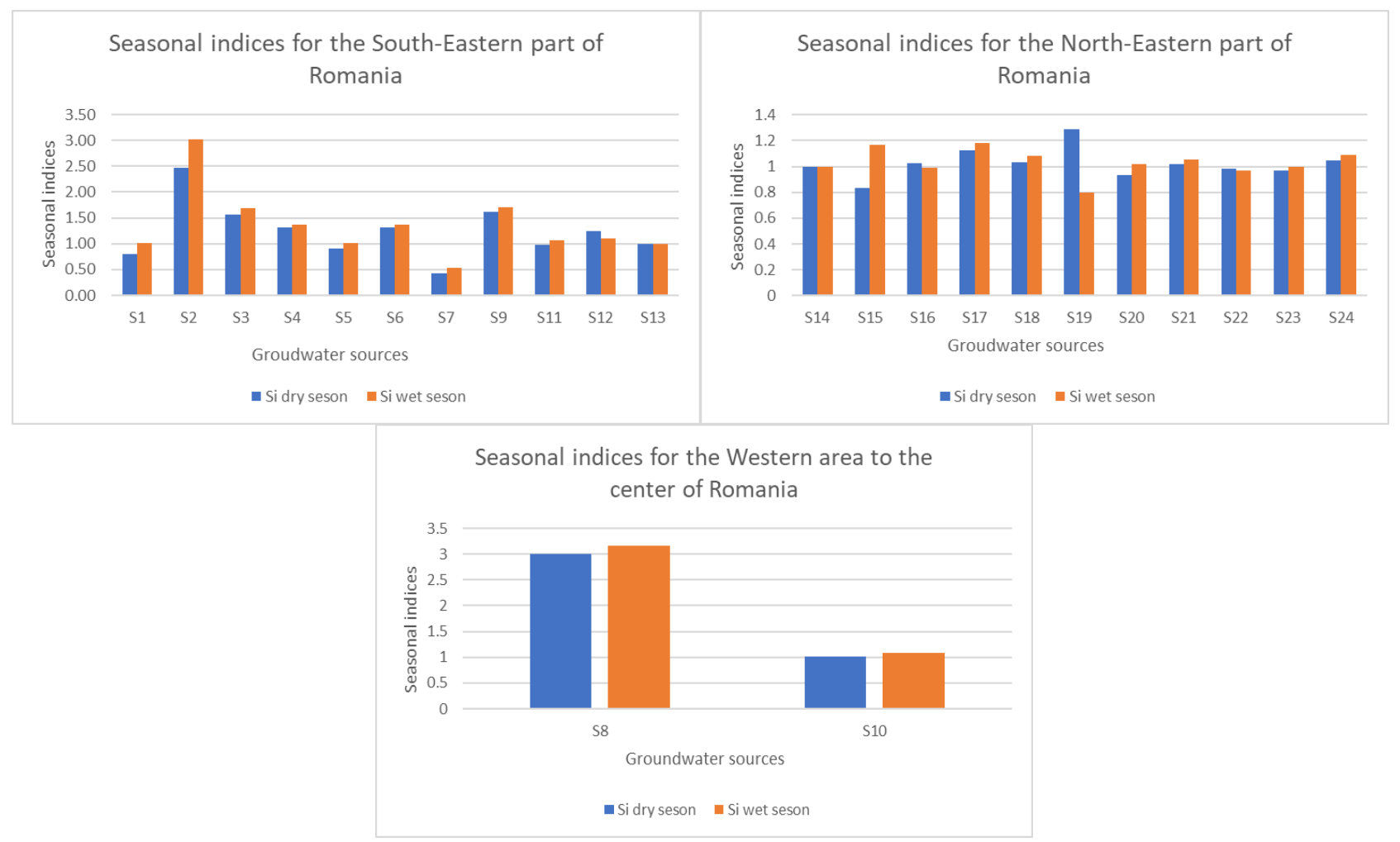

Fig. 6. Distribution of seasonal indices determined in the period Jan. 2016 - Feb. 2020

Seasonal indices were calculated according to the following equation:

$$
S i=X i / x i
$$


where $S i$ is the seasonal index, $X i$ is the mean nitrate concentration in a month for each season, $x$ is the annual mean nitrate

The temporal distribution of nitrates from groundwater in the selected locations shows a minimal fluctuation depending on the values obtained for the two seasonal indices. The data obtained during the evaluated period could have been influenced by the amount of precipitation, by temperature variation as well as by the different climatic types from each area. As can be seen from the small variation in the values of

\section{CONCLUSIONS}

In this paper, different types of statistical calculations were used to evaluate the spatiotemporal variation of groundwater quality in three geographical areas from Romania. From the obtained nitrate and nitrite concentration data there can be observed similar characteristics of groundwater. The determined nitrate concentration values were situated between the method limit of quantification (LOQ) and $8.03 \mathrm{mg} / \mathrm{L}$, which are lower than

\section{ACKNOWLEDGEMENT}

The authors acknowledge the financial support provided by the Ministry of Education and Research through the "Program Operational

\section{REFERENCES}

[1] PRASANTH, S.V.S, MAGESH, N.S, JITHESHLAL, K.V., CHANDRASEKAR, N., GANGADHAR, K., Appl. Water. Sci., no. 2, 2012, p. 165.

[2] KHAN, R., JHARIA, D.C., J. Geol. Soc. India., no. 90, 2017, p.69.

[3] BELKHIRI, L., MOUNI, L., Appl. Water. Sci., no. 2, 2012, p. 127.

[4] KUMAR, S.K, LOGESHKUMARAN, A., MAGESH, N.S., GODSON, P.S, CHANDRASEKAR, N., Appl. Water. Sci., 5, no. 4, 2014, p. 335.

[5] KUMAR, N., KUMAR, S., SINGH, D.P., Int. J. Environ. Sci., 6, no.3, 2015, p. 376.

[6] MANORAMA, S., PAULSAMY, S., Proceedings of the 11th Urban Environment Symposium (UES), Germany, 2013, p. 459.

[7] JHARIYA, D.C., KUMAR, T., PALC, D., DEWANGAND, P.K., J. Geol. Soc. India, no. 89, 2017, p. 453. concentration, and $i$ is the numbers of the month $(i=1-6)$ [29].

seasonal indices, they can give us information due perhaps to changes in the volume of a river basin related to climatic events that occur near the assessed area and the water deficit represented by atmospheric evaporation. The results obtained in this study showed that the concentrations of nitrites and nitrates, from all the investigated areas, were situated below the maximum allowed limits.

maximum allowable concentrations regulated by Government Decision no. 53/2009. In the case of the nitrite parameter, the determinate concentrations were bellow method LOQ. Therefore, excessive use of chemical fertilizers used in agriculture, as well as other types of industrial and municipal waste, could influence the quality of groundwater used for drinking purposes.

Competitivitate" program, Action A.1.2.3. section G, project no. 55/05.09.2016, subsidiary contract number ID-07563/02.06.2020.

[8] SWARTJES, F.A., OTTE, P.F., Water. Res., no.119, 2017, p. 187.

[9] SELVAKUMAR, S., CHANDRASEKAR, N., KUMAR, G., Water Resour. Indus., no. 17, 2017, p. 26.

[10] SUTHAR, S., BISHNOI, P., SINGH, S., MUTIYAR, P.K., NEMA, A.K, PATIL NS, J. Hazard Mat., no. 171, 2009, p. 189.

[11] SINGH, P., CHATURVEDI, R.K, MISHRA, A., KUMARI, L., SINGH, R., PAL, D.B., Environ. Monit. Assess., no. 187, 2015, p.1.

[12] ADDISCOTT, T.M., WHITMORE, A.P., POWLSON D.S., CAB International, 1991, p. 170.

[13] VIDAL, M., MELGAR, J., OPEZ, A.L., SANTOALLA, M.C.J, Environ. Manag., no. 60, 2000, p. 215.

[14] KUNDU, M.C., MANDAL, B. D., SARKAR, D., Environ. Monit. Assess., no.146, 
2008, p. 183.

[15] FAN, A.M., STEINBERG, V, E, Regul Toxicol Pharmacol., no. 23, 1996, p. 35.

[16] GELBERG, K.H., CHURCH, L., Environ. Res. Sect. A., no. 80, 1999, p. 30.

[17] GULIS, G., CZOMPOLYOVA, M., CASEY, G., Environ. Res. Sect. A., no.88, 2002, p. 182.

[18] ROWLAND, I.R., GRANLI, T., BOCKMAN, O.C., KEY, P.E., MASSEY, R.C., Carcinogenesis, no. 12, 1991, p. 1395.

[19] TRICKER, A.R., PREUSSMANN, R., Mutat. Res., no. 259, 1991, p. 277.

[20] GALAON, T., CRUCERU, L., PETRE, J., PASCU, L.F., IANCU, V.I., NICULESCU, M, J. Environ. Prot. Ecol., 17 no.1, 2016 p. 74.

[21] OSHIMA, H., MIYOSHI, N., Genes. Environ., 32 no. 3, 2010, p. 43.

[22] WEISENBERG, E., GRAUER, F., BARON, Y., RAJSTEIN, J. Ecotoxicol. Environ. Saf., no. 6, 1982, p. 97.

[23] NAS (National Academy of Sciences), Drinking water and health. Safe Drinking Water Committee, Washington, DC, 1977.

[24] MOLLER, H., LANDT, J., PEDERSEN, E., JENSEN, P., AUTRUP, H., JENSEN, O.M., Cancer. Res., no. 49, 1989, p. 3117.

[25] KAMIYAMA, S., OHSHIMA, H., SHIMADA, A., SAITO, N., BOURGADE, M.C., ZIEGLER, P., ET AL., IARC Sci Publ.,no. 84, 1987, p. 479.

[26] LU, S.H., OHSHIMA, H., FU, H.M., TIAN, Y., LI, F.M., BLETTNER, M., et al.
Cancer Res., no. 46, 1986, p. 1485.

[27] YI, Z., OHSHIMA, H., BOUVIER, G., ROY, P., ZHONG, J., L.I., B., et al. Cancer Epidemiol Biomarkers Prev., no. 2, 1993, p.195.

[28] SANSFICA, M. Y., PITAWALA, A., GUNATILAKE, J., PADDY, Water. Environ., no. 8,2010, p. 71 .

[29] RANTANEN, P., L. , MELLIN I., MINNA, M., KEINANEN, M.,M, AHONEN, M., VAHALA, R , Int. J. Environ. Res. Public Health, 15, no. 8, 2018, p. 1756.

[30] WHO, 2004. Guidelines for DrinkingWater Quality, third ed. WHO, Geneva, Switzerland

[31] Government Decision no. 53 of 29 January 2009 (update) for the approval of the National Water Protection Plan against pollution and damage [in Romanian].

[32] Order no. 621 of July 7, 2014 on the approval of threshold values for groundwater in Romania [in Romanian].

[33] ISO 7890-3:1988, Water quality Determination of nitrate - Part 3: Spectrometric method using sulfosalicylic acid.

[34]SR EN 26777:02, SR ISO 26777:02/C91:06, Water quality -

Determination of nitrite - Molecular absorption spectrometric method.

[35] KAZI, T., G., ARAIN, M., B., JAMALI, M., K., JALBANI, N., AFRIDI, H., I., SARFRAZ R., A., BAIG, J., A., SHAH, A.Q., Ecotoxicol. Environ. Saf., no. 72, 2009, p. 301. 